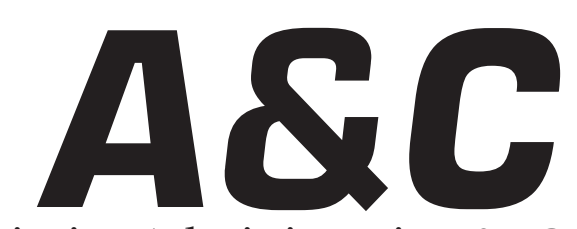

Revista de Direito Administrativo \& Constitucional

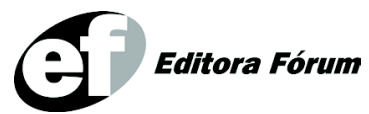

ISSN 1516-3210 


\section{A\&C REVISTA DE DIREITO ADMINISTRATIVO E CONSTITUCIONAL}

IPDA

Instituto Paranaense

de Direito Administrativo

Direção Geral

Romeu Felipe Bacellar Filho

Direção Editorial

Paulo Roberto Ferreira Motta

Direção Executiva

Emerson Gabardo

Conselho de Redação

Edgar Chiuratto Guimarães

Adriana da Costa Ricardo Schier

Célio Heitor Guimarães

\section{Conselho Editorial}

Adilson Abreu Dallari

Alice Gonzáles Borges

Carlos Ari Sundfeld

Carlos Ayres Britto

Carlos Delpiazzo

Cármen Lúcia Antunes Rocha

Celso Antônio Bandeira de Mello

Clèmerson Merlin Clève

Clóvis Beznos

Enrique Silva Cimma

Eros Roberto Grau

Fabrício Motta

Guilhermo Andrés Muñoz (in memoriam)

Jaime Rodríguez-Arana Muñoz

Jorge Luís Salomoni

José Carlos Abraão
José Eduardo Martins Cardoso
José Luís Said
José Mario Serrate Paz
Juan Pablo Cajarville Peruffo
Juarez Freitas
Julio Rodolfo Comadira
Luís Enrique Chase Plate
Lúcia Valle Figueiredo
Manoel de Oliveira Franco Sobrinho
(in memoriam)
Marçal Justen Filho
Marcelo Figueiredo
Márcio Cammarosano
Maria Cristina Cesar de Oliveira

Nelson Figueiredo

Odilon Borges Junior

Pascual Caiella

Paulo Eduardo Garrido Modesto

Paulo Henrique Blasi

Paulo Neves de Carvalho (in memoriam)

Paulo Ricardo Schier

Pedro Paulo de Almeida Dutra

Regina Maria Macedo Nery Ferrari

Rogério Gesta Leal

Rolando Pantoja Bauzá

Sérgio Ferraz

Valmir Pontes Filho

Yara Stropa

Weida Zancaner

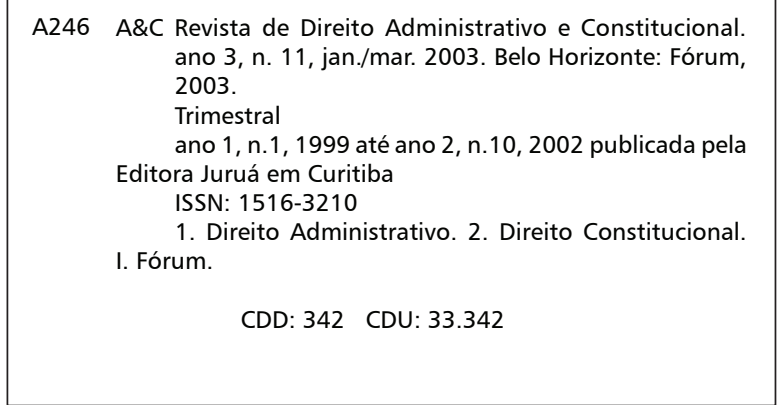

(c) Editora Fórum Ltda. 2006

Todos os direitos reservados. É proibida a reprodução total ou parcial, de qualquer forma ou por qualquer meio eletrônico ou mecânico, inclusive através de processos xerográficos, de fotocópias ou de gravação, sem permissão por escrito do possuidor dos direitos de cópias (Lei $n^{\circ}$ 9.610, de 19.02.1998).

Editora Fórum Ltda

Av. Afonso Pena, 2770 - 15\%16ª andar - Funcionários

CEP 30130-007 - Belo Horizonte/MG - Brasil

Tel.: 08007043737

Internet: www.editoraforum.com.br

e-mail: editoraforum@editoraforum.com.br
Editor responsável: Luís Cláudio Rodrigues Ferreira Projeto gráfico e diagramação: Luis Alberto Pimenta Revisora: Olga M. A. Sousa

Pesquisa jurídica: Fátima Ribeiro - OAB/MG 74868

Bibliotecária: Alessandra Rodrigues da Silva - CRB 2778/

MG 6a Região

Os conceitos e opiniões expressas nos trabalhos assinados são de responsabilidade exclusiva de seus autores.

Impressa no Brasil / Printed in Brazil

Distribuída em todo Território Nacional 


\title{
A responsabilidade civil do Estado por omissão legislativa
}

\begin{abstract}
Cristiana Fortini
Doutora em Direito Administrativo pela UFMG. Professora de Direito Administrativo da PUC Minas. Professora do Centro Universitário Metodista Izabela Hendrix. Professora do mestrado em Direito da Unipac. Diretora de Feitos Especiais da Procuradoria de Belo Horizonte. $1^{\text {a }}$ Vice-Presidente do Instituto Mineiro de Direito Administrativo
\end{abstract}

Tatiana Santos de Souza

Acadêmica do $10^{\circ}$ período do curso de Direito da PUC Minas

Sumário: 1 A responsabilidade civil do Estado - 2 A responsabilidade civil por ato omissivo do Estado - 3 A responsabilidade por ato legislativo - $4 \mathrm{~A}$ eficácia das normas constitucionais - 5 A inconstitucionalidade por omissão - 6 A responsabilidade civil do Estado na inconstitucionalidade por omissão legislativa - 7 Considerações finais - Referências

Palavras-chave: Estado. Responsabilidade civil. Princípio da responsabilidade civil. Omissão legislativa. Indenização.

\section{A responsabilidade civil do Estado}

A responsabilidade civil extracontratual do Estado consiste na obrigação que lhe é atribuída de recompor os danos causados a terceiros por seus atos e comportamentos unilaterais, podendo ser tanto comissivos quanto omissivos, lícitos e ilícitos, materiais ou jurídicos, que lhe sejam imputáveis. ${ }^{1}$

O princípio da responsabilidade civil extracontratual do Estado foi uma conquista histórica, uma vez que, antigamente, vigia o princípio da irresponsabilidade do Estado. ${ }^{2}$

A teoria da responsabilidade somente pôde lançar suas idéias com a instituição do Estado de Direito, quando surgiram as primeiras manifestações a fim de que o Estado indenizasse os prejuízos causados por atos de seus agentes. ${ }^{3}$ Neste período, a despeito da ausência de legislação quanto à matéria, se iniciou um caminho que conduziria da irresponsabilidade do Estado para a perquirição da existência de culpa na prática de seus atos, que, se constatada, resultava na responsabilidade.

\footnotetext{
O autor conceitua a responsabilidade patrimonial extracontratual do Estado como "a obrigação que Ihe incumbe de reparar economicamente os danos lesivos à esfera juridicamente garantida de outrem e que Ihe sejam imputáveis em decorrência de comportamentos unilaterais, lícitos ou ilícitos, comissivos ou omissivos, materiais ou jurídicos". BANDEIRA DE MELLO. Curso de direito administrativo, p. 799.

2 BANDEIRA DE MELLO. Curso de direito administrativo, p. 807.

3 FARIA. Curso de direito administrativo positivo, p. 422.
} 
Assim, ainda que a responsabilidade do Estado não fosse admitida de forma geral e absoluta, foi reconhecida pela primeira vez no século XIX, tornando-se, desde então, um relevante princípio a ser aplicado. ${ }^{4}$

O estágio atual não foi conquistado de forma abrupta. Ao contrário, a concretização da responsabilidade objetiva do Estado ocorreu de forma paulatina, uma vez que a superação da tese da irresponsabilidade levou, em princípio, ao uso de teorias civilistas, para as quais seria de inegável importância o reconhecimento da presença de dolo ou culpa. A responsabilidade objetiva surge a partir da constatação de que o tratamento dispensado aos particulares, no que concerne à responsabilidade civil, não pode ser compartilhado e/ou estendido ao Estado.

Compreendeu-se, por exemplo, que a concessão ao Estado de prerrogativas instrumentais ao alcance do interesse público deve ser compensada com a intensificação de sua responsabilidade.

A responsabilidade extracontratual do Estado pode advir tanto de atos ilícitos quanto lícitos. No caso dos atos ilícitos, o fundamento da responsabilidade está no princípio da legalidade, contemporaneamente revisitado, para se falar em princípio da juridicidade, ou seja, legalidade apimentada pela proporcionalidade, razoabilidade, segurança jurídica, transparência e boa-fé, ${ }^{5}$ exigindo que os agentes públicos atuem em conformidade com o Direito.

No que se refere aos atos lícitos, a justificativa da responsabilidade embasa-se no Princípio da Igualdade, não sendo justo que alguns suportem sozinhos os danos excessivos causados por atividades desempenhadas pelo Estado no interesse e benefício de todos. ${ }^{6}$

Ademais, este comportamento há de derivar de um "agente", 7 conforme preconiza a Constituição da República. Assim, o sujeito ativo do dano é qualquer pessoa que pratica função pública, mesmo que irregularmente investida. ${ }^{8}$

\footnotetext{
4 BANDEIRA DE MELLO. Curso de direito administrativo, p. 808.

BANDEIRA DE MELLO. Curso de direito administrativo, p. 813.

BANDEIRA DE MELLO. Curso de direito administrativo, p. 813.

7 Há um grupo de agentes que, mesmo sem ter investido de forma normal e regular, executam uma função pública em nome do Estado. Estes são os agentes de fato. Há duas categorias a que podem pertencer: agentes necessários e agentes putativos. Os primeiros irão praticar atos, executar atividades em situações de excepcionalidade. Já os segundos desempenham atividade pública na qual se presume a legitimidade, ainda que ausente o normal procedimento de investidura, como o servidor investido sem aprovação em concurso público. Como regra, os atos dos agentes necessários são confirmados pelo Poder Público. Quanto aos atos dos agentes putativos, alguns podem ser questionados, embora devam ser convalidados pela teoria da aparência. Mas o agente de fato em momento algum poderá usurpar a competência funcional dos agentes em geral. CARVALHO FILHO. Manual de direito administrativo, p. 490-491. É importante destacar que, no caso da usurpação da função, o ato será inexistente.
}

A \& C R. de Dir. Administrativo e Constitucional, Belo Horizonte, ano 6, n. 26, p. 221-234, out./dez. 2006 
Essa expressão "agente" foi propositadamente incluída no texto da Lei Maior, a fim de abarcar todos aqueles que de alguma forma contribuam com o Estado, independentemente de vínculo jurídico ou remuneração. ${ }^{9}$

Ainda que o Estado não possua ação e vontade próprias, no seu sentido literal, elas serão manifestadas pelos agentes estatais. Logo, não se bipartem Estado e agente, que são, na verdade, considerados um único ser, de maneira que, se o autor do dano é um agente estatal ou se possui este status jurídico, ${ }^{10}$ estará refletida a vontade do Estado e, conseqüentemente, a sua responsabilidade.

A natureza do dano não é razão suficiente para excluir, isentar o Estado de sua responsabilidade. Assim, tanto é indenizável o dano patrimonial, quanto o moral, desde que o lesado apresente provas suficientes para demonstrar o prejuízo que lhe foi causado. ${ }^{11}$

A responsabilidade será classificada em subjetiva ou objetiva. Aquela é o dever de indenizar em face de um dano causado a outrem, desde que haja culpa, apurada em igualdade de condições como a de um particular. ${ }^{12}$

No que tange ao Estado, em razão dos princípios publicísticos, não há mais que se examinar a culpa para se atribuir a responsabilidade. Esta noção, própria do Direito Civil, foi substituída pela idéia da "falta do serviço”, que implica na culpa do serviço quando ele não funciona devendo funcionar, quando funciona mal ou funciona atrasado. ${ }^{13}$

A partir da Constituição de 1946, o Brasil adotou em seu ordenamento jurídico a responsabilidade objetiva do Estado como regra a ser seguida, não mais havendo que se perquirir sobre culpa e ilicitude da conduta do Estado para que se configurasse sua obrigação de reparar os prejuízos causados a terceiros. ${ }^{14}$

A concretização da responsabilidade objetiva, já há muito instituída na França, resultou da constatação de que o Estado não poderia merecer o mesmo tratamento conferido aos particulares, no que tange à responsabilidade civil. Como o Estado goza de uma posição diferen-

\footnotetext{
${ }^{8}$ BASTOS. Curso de direito administrativo, p. 193

9 GASPARINI. Direito administrativo, p. 913-914.

10 BANDEIRA DE MELLO. Curso de direito administrativo, p. 814

${ }^{11}$ CARVALHO FILHO. Manual de direito administrativo, p. 458.

12 DI PIETRO. Direito administrativo, p. 563.

13 BANDEIRA DE MELLO. Curso de direito administrativo, p. 808-809.

${ }^{14}$ FERRAZ, Luciano. Responsabilidade do Estado por omissão legislativa: o caso do art. 37, X da Constituição da República. In: FREITAS, Juarez (Org.). Responsabilidade civil do Estado. São Paulo: Malheiros, 2006. p. 213.
} 
ciada em face dos particulares, pois detentor de uma série de prerrogativas voltadas para assegurar o interesse público, sua responsabilidade há de adquirir princípios próprios, tornando-se mais intensa, quando comparada ao dever de reparar de que cuida o direito civil. ${ }^{15}$

Deste modo, com a evolução do Estado evoluiu também a teoria da responsabilidade de forma a expandir os tentáculos da responsabilidade civil, ${ }^{16}$ para alcançar inclusive os atos realizados por pessoas jurídicas de direito privado, estranhas à máquina estatal, que se dediquem à prestação de serviço público. O dispositivo abaixo, contido na Constituição da República, retrata tal preocupação:

\section{Art. 37. (...)}

$\S 6^{\circ}$ As pessoas jurídicas de direito público e as de direito privado prestadoras de serviços públicos responderão pelos danos que seus agentes, nessa qualidade, causarem a terceiros, assegurado o direito de regresso contra o responsável nos casos de dolo ou culpa.

A ampliação da responsabilidade civil objetiva, que ultrapassa as muralhas do Estado e de suas entidades para alcançar as pessoas jurídicas criadas pela iniciativa privada, é justificada tendo em vista a natureza da tarefa a elas conferida.

Ao se dedicar à prestação de serviço público, ainda que em nome próprio, as concessionárias e permissionárias estão a desenvolver atividade típica do Estado. Em face disso, o ordenamento jurídico se lhes atribui uma série de prerrogativas, merecendo especial destaque a possibilidade de desapropriarem e instituírem servidão administrativa (art. 31, inciso VI, da Lei $\left.\mathrm{n}^{\mathrm{o}} 8.987 / 95\right)$. Ora, se o ordenamento jurídico, em prol do interesse público, fixa algumas prerrogativas instrumentais para o manuseio da concessionária, outro entendimento não seria correto, para balancear vantagens e desvantagens, salvo o de estender o ônus da responsabilidade civil objetiva a tais empresas.

Assim, a decisão proferida pelo Supremo Tribunal Federal, relatada pelo eminente Ministro Carlos Veloso, nos autos do Recurso Extraordinário $\mathrm{n}^{\mathrm{o}} 262651$, julgado em 16.11.2005, na qual se consignou o entendimento de que a responsabilidade civil das concessionárias é objetiva apenas com relação aos danos causados aos usuários do serviço público prestado, parece-

\footnotetext{
15 BANDEIRA DE MELLO. Curso de direito administrativo, p. 803-804.

${ }^{16}$ BANDEIRA DE MELLO. Curso de direito administrativo, p. 804.
}

A \& C R. de Dir. Administrativo e Constitucional, Belo Horizonte, ano 6, n. 26, p. 221-234, out./dez. 2006 
nos conflitar com o texto da Constituição da República que não promove distinção de tratamento entre usuários e não usuários, pois o art. $37, \S 6^{\circ}$, protege "terceiros", independentemente de quem venha a figurar como tal.

\section{A responsabilidade civil por ato omissivo do Estado}

A teoria da responsabilidade do Estado evoluiu, como visto, a partir da Constituição da República de 1946, tendo sido incrementada com a Constituição de 1988. Persistem, todavia, algumas indagações sobre a matéria. ${ }^{17}$

O principal questionamento envolve a natureza da responsabilidade civil nas hipóteses em que o gravame adveio da inércia estatal.

Celso Antônio Bandeira de Mello, eminente jurista e professor, titular de pensamento assimilado por boa parte da doutrina e da jurisprudência, adota o entendimento segundo o qual, diante de omissão do Estado, deverá ser aplicada a teoria da responsabilidade subjetiva. Para o autor, se o Estado não agiu, não será de se lhe atribuir a autoria do dano. ${ }^{18}$ Logo, somente poderá ser responsabilizado quando descumprido o dever que lhe cabia de evitar o evento lesivo. ${ }^{19}$ Neste momento está a se indagar a culpa ou o dolo do Estado, o que afasta a tese da responsabilidade objetiva. ${ }^{20}$

Os comportamentos omissivos do Estado que acarretam, em tese, a responsabilização são: os fatos da natureza que geram lesão e cujos efeitos poderiam ter sido contornados (aliam-se, assim, a circunstância natural e a desídia estatal), o comportamento material de terceiros nas hipóteses

\footnotetext{
17 BANDEIRA DE MELLO. Curso de direito administrativo, p. 815-816.

${ }^{18}$ Celso Antônio Bandeira de Mello assegura que "a responsabilidade por 'falta de serviço', falha no serviço ou culpa no serviço não é, de modo algum, modalidade de responsabilidade objetiva, ao contrário do que entre nós e alhures, às vezes, tem-se inadvertidamente suposto. É responsabilidade subjetiva porque baseada na culpa (ou dolo), como sempre advertiu o Prof. Oswaldo Aranha Bandeira de Mello". CARVALHO FILHO, José dos Santos. Manual de direito administrativo. 15. ed. ver., ampl. e atual. Rio de Janeiro: Lúmen Júris, 2006. p. 809. Todavia, com opinião oposta, Hely Lopes Meirelles, referindo-se ao artigo 37, \$6 que trata da responsabilidade civil objetiva, sustenta que a Constituição atual usou acertadamente o vocábulo agente, abrangendo para fins de responsabilidade civil todas as pessoas que são incumbidas de realizar algum serviço público, sendo essencial que o agente da Administração haja praticado o ato ou a omissão administrativa no exercício de suas atribuições ou a pretexto de exercê-las. p. 626-627.

${ }^{19}$ DINIZ. A responsabilidade do Estado na inconstitucionalidade por omissão, p. 117.

${ }^{20}$ BRASIL. Supremo Tribunal Federal. RE 369820/RS. Relator: Min Carlos Velloso DJ Brasília - DF 04 nov. 2003. "Tratando-se de ato omissivo do Poder Público, a responsabilidade civil por tal ato é subjetiva, pelo que exige dolo ou culpa". Com o mesmo entendimento: BRASIL. Supremo Tribunal Federal. 235524/AC. Relator: Min. Sepúlveda Pertence. DJ, Brasília, DF, 30 jun. 2004. Acompanhando os julgados do Supremo Tribunal Federal, Celso Antônio Bandeira de Mello, p. 809. Deste modo, embora seja este o entendimento que prepondera atualmente, o doutrinador Hely Lopes Meirelles entende que a Teoria da Responsabilidade O b j e t i va a b a r c a r a t a n t o os a tos com is si vos quanto os atos omissivos: "Nessa substituição da responsabilidade

individual do servidor pela responsabilidade genérica do Poder Público, cobrindo o risco da sua ação ou omissão, é que se assenta a teoria da responsabilidade objetiva da Administração, vale dizer, responsabilidade sem culpa, pela só ocorrência da falta anônima do serviço, porque esta falta está, precisamente, na área dos
} 
em que o Poder Público podia e devia ter evitado o gravame e os danos decorrentes de uma situação produzida pelo Estado. ${ }^{21}$

A subjetividade da responsabilidade nas inações estatais deriva da impossibilidade de se afirmar, de antemão, o descompromisso do Estado com seus deveres. Portanto, nesses casos, há de se comprovar que o Estado tinha reais condições de evitar o prejuízo, mas omitiu-se inaceitavelmente em seu dever. Apenas assim se configuraria a sua responsabilidade. ${ }^{22}$

Ademais, importa anotar, para a hipótese de serviço prestado de maneira "defeituosa", que será necessário levar em conta um termo médio que, de forma legítima, se poderia exigir da atividade em questão. ${ }^{23}$ Assim, ao magistrado caberá ponderar se era ou não exigível a ação impeditiva do dano. ${ }^{24}$

A responsabilidade por omissão estatal ocorre quando a conduta que gerou o dano se apresenta como prática de um comportamento proibido de forma deliberada ou indesejado desatendimento dos padrões de empenho, atenção ou habilidades normais, legalmente exigíveis, de modo a afetar um direito tutelado ${ }^{25}$ e, portanto, que enseja reparação.

\section{$3 \mathrm{~A}$ responsabilidade por ato legislativo}

A responsabilidade civil do Estado legislador foi tratada primeiramente por Amaro Cavalcanti, em 1904, para quem haveria responsabilidade apenas quando as normas expressamente a admitissem.

Com a expansão da intervenção do Estado no domínio econômico, ampliou-se a admissão da responsabilidade do Estado legislador. Assim, com o surgimento da República, alguns autores entenderam não mais haver dúvida quanto à responsabilidade do Estado em face de leis inconstitucionais. ${ }^{26}$ Neste sentido, não admitindo que o Estado ficasse imune aos danos causados pelos detentores de mandato político, que também se enquadram na conceituação de "agentes", ${ }^{27}$ Celso Antônio Bandeira de Mello, Yussef Said Cahali e Cretella Júnior reconheceram a responsabilidade do Estado legislador. ${ }^{28}$

\footnotetext{
21 BANDEIRA DE MELLO. Curso de direito administrativo, p. 823.

${ }^{22}$ CARVALHO FILHO. Manual de direito administrativo, p. 464.

23 BANDEIRA DE MELLO. Curso de direito administrativo, p. 811.

${ }^{24}$ O ilustre Ministro Aliomar Baleeiro já dizia que "a autoridade deverá guiar-se pela consciência de homem médio de seu tempo, perscrutando os propósitos dos autores do material suspeito" STF. RMS 18534.

${ }^{25}$ BANDEIRA DE MELLO. Curso de direito administrativo, p. 811.

${ }^{26}$ DINIZ. A responsabilidade do Estado na inconstitucionalidade por omissão, p. 113-114.
}

A \& C R. de Dir. Administrativo e Constitucional, Belo Horizonte, ano 6, n. 26, p. 221-234, out./dez. 2006 
Há, porém, autores cuja obra ainda hoje manifesta entendimento diferenciado. Mesmo diante de lei declarada inconstitucional, Hely Lopes Meirelles não admite a responsabilidade do Estado legislador, afirmando que a norma geral e abstrata não pode causar prejuízo ao particular, porque dirigida a toda a coletividade. Na visão do autor, somente se admitiria a responsabilidade se comprovada a culpa do Estado por meio da atuação dos seus agentes políticos, o que, entretanto, seria impossível de ocorrer no Regime Democrático, já que o próprio povo escolhe seus representantes legisladores. ${ }^{29}$ Assim, a responsabilidade não seria do Estado, e sim dos próprios particulares.

Acompanhando, sob o mesmo fundamento doutrinário do autor supracitado, está o doutrinador Celso Ribeiro Bastos. ${ }^{30}$

Todavia, os tribunais já reconheceram a responsabilidade do Estado no caso de danos provocados por leis declaradas inconstitucionais. ${ }^{31}$

A independência parlamentar não autoriza o descompromisso com a ordem constitucional. ${ }^{32}$

Logo, o Estado legislador que descumpre seu dever jurídico de elaborar leis compatíveis com a Constituição da República assume o dever de reparar prejuízos daí decorrentes. ${ }^{33}$

Outro ponto a merecer destaque é a "lei" de efeito concreto, cuja essência é de ato administrativo emitido pelo legislativo porque, ao atingir pessoas determinadas, perde o caráter de abstração e generalidade. ${ }^{34}$

\section{A eficácia das normas constitucionais}

A Constituição da República de 1988 construiu uma ordem jurídica embasada em normas que enunciam programas, tarefas e fins a serem buscados pelo Estado. Contudo, muitas dessas normas dependem da edição

\footnotetext{
${ }^{27}$ DINIZ. A responsabilidade do Estado na inconstitucionalidade por omissão, p. 115-116.

${ }^{28} \mathrm{Com}$ este pensamento, Hely Lopes Meirelles entende que somente de modo excepcional uma lei inconstitucional pode atingir o particular causando-lhe um dano injusto e reparável. Mas, se tal fato ocorresse, torna-se necessária a demonstração cabal da culpa do Estado, através da atuação de seus agentes políticos, mas isso se afigura indemonstrável no regime democrático, em que o próprio povo escolhe seus representantes para o legislativo. E completa da seguinte maneira: "Não encontramos, assim, fundamento jurídico para a responsabilização civil da Fazenda Pública por danos eventualmente causados por lei, ainda que declarada inconstitucional". p. 652-653.

${ }^{29}$ MEIRELLES. Direito administrativo brasileiro, p. 652-653.

30 BASTOS. Curso de direito administrativo, p. 194.

${ }^{31}$ BRASIL. Supremo Tribunal Federal. RE no 153.464. Relator: Min. Celso de Mello. Despacho de 02 set. 1992: "O Estado responde civilmente por danos causados aos particulares pelo desempenho inconstitucional da função de legislar".

32 FARIA. Curso de direito administrativo positivo, p. 436.

${ }^{33}$ FARIA. Curso de direito administrativo positivo, p. 437.

${ }^{34}$ CARVALHO FILHO. Manual de direito administrativo, p. 468.
} 
de outras normas para que possam produzir seus efeitos. ${ }^{35}$

As normas constitucionais que dependem de normatividade ulterior são designadas normas constitucionais de eficácia contida e de eficácia limitada.

As primeiras são aquelas cujos interesses relativos a determinada matéria foram regulados de modo suficiente, mas há espaço para restrita atuação por parte da competência discricionária do poder público, nos termos que a lei estabelecer (exemplificativamente, o art. $5^{\circ}$ XIII, CF, em que é livre o exercício de qualquer trabalho, atendidas as qualificações profissionais que a lei estabelecer). ${ }^{36}$

As demais apresentam aplicabilidade indireta, mediata e reduzida, pois seus interesses só serão concretizados com uma normatividade posterior que lhes desenvolva a aplicabilidade (ex.: art. 192, §3º, CF as taxas de juros reais não poderão ser superiores a $12 \%$ a.a., a cobrança acima consiste em crime de usura, nos termos que a lei determinar). ${ }^{37}$

A supremacia constitucional indica que a efetividade de suas normas está vinculada à obrigação de todos os poderes se comprometerem com a implementação de todo o conjunto normativo para a sociedade. ${ }^{38}$

As leis que se destinam a concretizar a eficácias das normas constitucionais, se não forem editadas, consubstanciarão omissão repudiada pela própria Constituição. ${ }^{39}$

\section{A inconstitucionalidade por omissão}

É notória a existência de muitos dispositivos de grande relevância social que ainda carecem de regulamentação. ${ }^{40}$

O Estado, por conseguinte, se não agir ou agir de forma deficitária, poderá ocasionar um dano. ${ }^{41}$

Portanto, como este dano decorre de uma omissão, seria de se cogitar da aplicação da teoria da responsabilidade subjetiva, somente incorrendo em responsabilidade se presente o dever legal de evitar o evento lesivo. ${ }^{42}$

O direito brasileiro, ao adotar o controle de constitucionalidade

\footnotetext{
${ }^{35}$ DINIZ. A responsabilidade do Estado na inconstitucionalidade por omissão, p. 44.

${ }^{36}$ MORAES. Direito constitucional, p. 41.

${ }^{37}$ MORAES. Direito constitucional, p. 41

${ }^{38}$ DINIZ. A responsabilidade do Estado na inconstitucionalidade por omissão, p. 23.

39 SOARES. Teoria do Estado: o substrato clássico e os novos paradigmas como pré-compreensão para o direito constitucional, p. 468.

${ }^{40}$ DINIZ. A responsabilidade do Estado na inconstitucionalidade por omissão, p. 46

${ }^{41}$ BANDEIRA DE MELLO. Curso de direito administrativo, p. 820.
}

A \& C R. de Dir. Administrativo e Constitucional, Belo Horizonte, ano 6, n. 26, p. 221-234, out./dez. 2006 
das leis, reconhece que o Estado se submete à ordem jurídica. ${ }^{43}$

Deste modo, a argüição de inconstitucionalidade por omissão se presta a denunciar a ineficiência estatal para controlar o exercício do poder-dever do Estado de legislar e assim garantir a efetividade das normas constitucionais. $^{44}$

Deste modo, a responsabilidade civil funcionaria como um mecanismo de sanção para a inércia do Estado diante de uma inconstitucionalidade por omissão. ${ }^{45}$

O legislador da Constituição da República de 1988 buscou atribuir plena eficácia às normas que dependem de complemento, ao prever as ações diretas de inconstitucionalidade. ${ }^{46} 47$

Há mais um instrumento destinado a suprir a omissão do Poder Público que visa a viabilizar o exercício de um direito, uma liberdade ou uma prerrogativa garantidos constitucionalmente, que é a via do mandado de injunção. ${ }^{48}$ Sua teleologia é, conjuntamente com a ação direta de inconstitucionalidade por omissão, "combater a síndrome de inefetividade" das normas constitucionais.

\section{A responsabilidade civil do Estado na inconstitucionalidade por omissão legislativa}

O exercício do mandato eletivo consiste em um verdadeiro poderdever de exercício das funções estatais, que implica em legislar, primordialmente, bem como exercer controle sobre as condutas da Administração Pública.

\footnotetext{
42 BANDEIRA DE MELLO. Curso de direito administrativo, p. 819.

${ }^{43}$ DINIZ. A responsabilidade do Estado na inconstitucionalidade por omissão, p. 116.

44 DINIZ. A responsabilidade do Estado na inconstitucionalidade por omissão, p. 141.

${ }^{45}$ BRASIL. Supremo Tribunal Federal. MI 543. Min. Celso de Mello. DJ, Brasília, DF, 24 maio 2002; BRASIL. Supremo Tribunal Federal. MI 562. Relator: Min. Carlos Velloso. DJ, Brasília, DF, 20 fev. 2003. O Supremo Tribunal Federal vem entendendo que "a mera superação dos prazos constitucionalmente assinalados é bastante para qualificar, como omissão juridicamente relevante, a inércia estatal, apta a ensejar, como ordinário efeito conseqüencial, o reconhecimento,"hit et nunc", de uma situação de inatividade constitucional".

${ }^{46}$ MORAES. Direito constitucional, p. 631

47 É possível ajuizar ação direta de inconstitucionalidade por omissão diante da inércia do Poder Público em face das normas constitucionais de eficácia limitada, quando se tratar de princípio institutivo e de caráter impositivo em que o legislador esteja incumbido de complementar. São também passíveis desta ação as normas programáticas ligadas ao princípio da legalidade, eis que dependem de outras normas para terem eficácia. Como não há prazo para a propositura desta ADIN, há que se examinar se já decorreu tempo razoável que permitisse a elaboração da norma complementadora. Ao Poder Legislativo dá-se conhecimento da declaração de inconstitucionalidade por omissão para adotar as medidas cabíveis. Porém, no exercício de sua função precípua, ele terá a conveniência a oportunidade de legislar, como já tratado, não podendo ser forçado por nenhum dos demais poderes a exercer o munus, que afrontaria a separação dos poderes. Entretanto, é fixada a omissão que possui efeitos ex tunc e contra todos e que permite a responsabilização por perdas e danos quando constatado o prejuízo sofrido. MORAES. Direito constitucional, p. 631-633.

${ }^{48}$ Será cabível diante das normas constitucionais de eficácia limitada com princípio institutivo e caráter impositivo, bem como normas programáticas ligadas ao princípio da legalidade, uma vez que dependem de normas posteriores para terem aplicabilidade. MORAES. Direito constitucional, p. 632.
} 
A omissão do Estado-legislador assim como a omissão do Estadoadministrador é capaz de ocasionar danos. A falta de norma regulamentadora de direito pode afetar o patrimônio do particular.

Não se pode perder de vista que a Constituição da República contém regra construída de forma a abarcar as condutas de qualquer agente público, não desonerando, portanto, o legislador. Com efeito, o art. $37, \S 6^{\circ}$, da Constituição da República disciplina os danos causados pelos agentes públicos, englobando, indiscutivelmente, os legisladores.

Duas situações têm provocado a atenção dos doutrinadores: a primeira diz respeito ao direito à revisão dos valores de remuneração, prevista na Constituição da República no art. 37, inciso X, e o direito de greve assegurado no mesmo art. 37, inciso VII.

O direito à revisão geral e anual, a despeito de previsto constitucionalmente, é constantemente ignorado pelos entes da federação que não a promovem.

O direito de greve, igualmente agasalhado pelo texto constitucional, não está disciplinado por meio de lei específica, tal como exige a Constituição da República.

A ausência de lei, em ambos os casos, gera prejuízo. Na hipótese do inciso X, o prejuízo patrimonial é evidente; mas, a ausência de lei que verse sobre o direito de greve também produz gravames para os servidores, sobretudo porque há considerável doutrina, além de variados julgados com destaque para o acórdão do STF, proferido nos autos do Mandado de Injunção $n^{\circ}$ 20, que assimilam o entendimento de que o inciso VII deve ser interpretado como norma de eficácia limitada. A impossibilidade de exercer o direito de greve, pela letargia do Poder Público, cria óbices consideráveis para o servidor, produzindo danos "indiretos" que não podem ser desprezados.

Estas são, pois, situações que atraem a atenção.

O dever de reparar os gravames que emergem da falta da lei a que alude o art. 37, X, da Constituição de 1988 tem sido interpretado sem uniformidade pela jurisprudência.

Há entendimentos favoráveis à condenação estatal, ${ }^{49}$ mas há decisões que não reconhecem o direito à reparação.

O próprio Supremo Tribunal Federal dá sinais de que a questão não está, nem de longe, pacificada.

Há acórdãos recentes que, de forma majoritária, concluem pela inviabilidade de indenização, alegando que significaria admitir, de modo 
indireto, que o Judiciário pode interferir na vontade política do Chefe do Executivo. ${ }^{50}$

Em decisão recentemente prolatada, nos autos do Recurso Extraordinário $n^{\circ} 484883$, o eminente Ministro Cezar Peluso deu provimento a recurso interposto pela União, contra acórdão que a havia condenado ao pagamento de indenização decorrente de sua inércia em confeccionar a lei concessiva do reajuste.

O eminente ministro aduziu que a competência para deflagrar o processo legislativo, que culminaria no aumento de remuneração, pertence ao Chefe do Executivo, não cabendo ao Judiciário fixar prazo e/ou indenização com o intuito de recompor o valor dos vencimentos. Decidir de forma contrária, segundo o Ministro, seria "deferir o que esta Corte tem reiteradamente negado", qual seja, a intervenção judicial em decisões que digam respeito a conveniências de ordem política.

Em contrapartida a esse entendimento há um voto ${ }^{51}$ de autoria do eminente Ministro Carlos Velloso no qual se reconhece a existência de omissão legislativa por parte da União. O eminente Ministro vislumbra a presença dos requisitos ensejadores da responsabilidade civil, afirmando existir "ação do próprio Estado causadora de danos, já que este, ao se abster de elaborar a nome jurídica, estaria agindo, hipótese de omissão sui generis, a caracterizar sua responsabilidade objetiva, dano indenizável, porque direto, real e certo, representado pela ausência da norma implementadora do direito assegurado, tendo em conta o fato de os recorrentes na pleitearem que o Poder Judiciário substitua o legislador, estabelecendo índice de reajuste e revisão por determinado período, mas sim aduzem apenas a existência de um dano e o conseqüente dever de indenizar".

Encontram-se outros julgados favoráveis à tese acolhida pelo Ministro Carlos Velloso. ${ }^{52}$

A questão que divide o STF está em detectar se o reconhecimento da mora e do direito à reparação traduz ou não ingerência indevida do Poder Judiciário que, inúmeras vezes, já se pronunciou pela impossibilidade de acolher pedido formulado por servidores interessados no

\footnotetext{
49 TJ RO. Decisão que antecedeu ao RE 450.063-9. DJ, 28 abr. 2006. "Inapropriada é a pretensão de servidor público de ver o Poder Executivo compelido, em decorrência de inconstitucionalidade por omissão, a conceder revisão geral e anual de salário por meio de ação revisional, o que não obsta, contudo, receber indenização, fundada na responsabilidade objetiva do Estado" (grifo nosso).

${ }^{50}$ BRASIL. Supremo Tribunal Federal. MS n. 22451. Relator: Min. Maurício Corrêa. DJ, Brasília, DF, 15 ago. 1997. No mesmo sentido: BRASIL. Supremo Tribunal Federal. RE 450.063-9. Relatório: Min. Cezar Peluso. DJ, Brasília, DF, 15 set. 2006.

${ }^{51}$ Recurso Extraordinário n 424584.
} 
estabelecimento do reajuste garantido constitucionalmente.

Se o Poder Judiciário não pode atuar como "legislador positivo", como usualmente destacam os julgados do STF, seria consentâneo com o princípio da separação dos poderes a imposição de condenação pela ausência da norma que materializaria o direito ao reajuste?

Não se trata, no fundo, de situações a merecer o mesmo tratamento? Assim, se inviável a "intromissão" do Poder Judiciário nas questões de "ordem política", sendo-lhe negado o direito de estabelecer o reajuste, não seria de se concluir pela existência de percalço a inviabilizar a fixação da condenação? Por outro ângulo: se o Judiciário reconhece a mora e, por conseguinte, condena o Estado, não seria de lhe permitir que exigisse a elaboração da lei concessiva do reajuste?

E mais: mesmo que ao Poder Judiciário possa intervir nesta seara, a responsabilidade em tela seria objetiva ou subjetiva?

Luciano Ferraz, após defender a condenação, argumenta que a responsabilidade seria objetiva e que o dano é indenizável por conta do descumprimento da regra constitucional.

Parece-nos, sem qualquer intenção de oferecer uma resposta definitiva ou satisfatória, que o problema demonstra que estamos a enfrentar, com novos olhos, questões que não são tão recentes.

O princípio da separação dos Poderes, costumeiramente lembrado pelo Poder Judiciário para inibir algumas pretensões que lhe são dirigidas, está, no mínimo, sendo revisitado, a fim de amoldá-lo ao presente. A retração do Judiciário, com base em tal princípio, tem sofrido reavaliações importantes. Assim, parece-nos que o voto do Ministro Carlos Velloso representa um marco relevante, porque nos convida a pensar sobre dogmas que, por vezes, não mais se justificam.

Será que o Poder Judiciário está impedido efetivamente de fixar o reajuste, quando este está assegurado na Constituição da República? Será que a via da reparação não seria uma tentativa de "margear" a resistência da jurisprudência, propondo aos magistrados algo (a indenização)

\footnotetext{
52 BRASIL. Supremo Tribunal Federal. MI n. 447-1. Relator: Min. Moreira Alves. DJ, Brasília, DF, 01 jul. 1974. "Impõe-se desde logo, que se assegure aos impetrantes a possibilidade de ajuizarem, com base no direito comum, ação de perdas e danos para se ressarcirem do prejuízo que tenham sofrido". Do mesmo modo: STF. MI 284. Relator: Min. Marco Aurélio. "Mora inconstitucional do Poder Legislativo". Torna-se "prescindível nova comunicação a instituição parlamentar assegurando-se aos impetrantes, 'desde logo', a possibilidade de ajuizarem, 'imediatamente', nos termos do direito comum ou ordinário, a ação de reparação de natureza econômica instituída em seu favor pelo preceito transitório".
} 
que, no final, produziria o mesmo resultado pretendido pelas ações mais "rotineiras" (o reajuste)? Portanto, decidir favoravelmente à condenação não seria uma forma oblíqua de rever o princípio da separação dos Poderes?

\section{Considerações finais}

As dúvidas são variadas e carecem de reflexões profundas.

Parece-nos, contudo, que a inércia legislativa merece ser combatida, sobretudo quando salta aos olhos.

Negar indiretamente, por meio de inação, o reajuste previsto na Constituição da República sem, ao menos, o oferecimento de qualquer justificativa pautada que fosse pela "cláusula da reserva do possível" representa lesão que clama pela atuação do Judiciário. Bastaria saber a extensão de tal interferência e ainda se seria satisfatória a fixação da condenação. A indenização é um passo indispensável para a obtenção da completa efetividade das normas constitucionais, embora não seja equivalente à obtenção da fruição do direito previsto constitucionalmente. ${ }^{53}$

\section{Referências}

ANGHER, Anne Joyce. Vade Mecum acadêmico de direito. 2. ed. São Paulo: Rideel, 2005. v. 1.

BANDEIRA DE MELLO, Celso Antônio. Curso de direito administrativo. 13. ed. ver. ampl. e atual. São Paulo: Malheiros, 2001.

BASTOS, Celso Ribeiro. Curso de direito administrativo. 4. ed. São Paulo: Saraiva, 2000.

CARVALHO FILHO, José dos Santos. Manual de direito administrativo. 15. ed. ver., ampl. e atual. Rio de Janeiro: Lúmen Júris, 2006.

DI PIETRO, Maria Sylvia Zanella. Direito administrativo. 18. ed. São Paulo: Atlas, 2005.

DINIZ, Rivanildo Pereira. A responsabilidade do Estado na inconstitucionalidade por omissão. Poços de Caldas: Sulminas, 2005.

FARIA, Edmur Ferreira de. Curso de direito administrativo positivo. 5. ed. rev e ampl. Belo Horizonte: Del Rey, 2004.

FERRAZ, Luciano. Responsabilidade do Estado por omissão legislativa o caso do art. 37, X da Constituição da República. In: FREITAS, Juarez (Org.). Responsabilidade civil do Estado. São Paulo: Malheiros, 2006.

FIGUEIREDO, Lúcia Valle. Curso de direito administrativo. 5. ed. rev., atual. e ampl. São Paulo: Malheiros, 2001.

${ }^{53}$ DINIZ. A responsabilidade do Estado na inconstitucionalidade por omissão, p. 128-129. 
FROTA, Hidemberg Alves de. A essência do direito público no Estado Democrático de Direito. Revista do Instituto de Advogados de Minas Gerais, Belo Horizonte, n. 11, 2005.

GASPARINI, Diogenes. Direito administrativo. 10. ed. ver. e atual. São Paulo: Saraiva, 2005.

IHERING, Rudolf von. A luta pelo direito. Tradução e notas Edson Bini. Bauru: Edipro, 2001.

MEIRELLES, Hely Lopes. Direito administrativo brasileiro. 31. ed. atual. São Paulo: Malheiros, 2005.

MORAES, Alexandre de. Direito constitucional. 13. ed. São Paulo: Atlas, 2003.

SAMPAIO, José Adércio Leite. A Constituição reinventada pela jurisdição constitucional. Belo Horizonte: Del Rey, 2002.

SOARES, Mário Lúcio Quintão. Teoria do Estado: o substrato clássico e os novos paradigmas como pré-compreensão para o direito constitucional. Belo Horizonte: Del Rey, 2001.

Informação bibliográfica deste texto, conforme a NBR 6023:2002 da Associação Brasileira de Normas Técnicas (ABNT):

FORTINI, Cristiana; SOUZA, Tatiana Santos de. A responsabilidade civil do Estado por omissão legislativa. A\&C Revista de Direito Administrativo e Constitucional, Belo Horizonte, ano 6, n. 26, p. 221-234, out./dez. 2006. 